\title{
Historical deforestation locally increased the intensity of hot days in northern mid-latitudes
}

\section{Journal Article}

\section{Author(s):}

Lejeune, Quentin; Davin, Edouard Léopold (i); Gudmundsson, Lukas (D); Winckler, Johannes; Seneviratne, Sonia I. (1)

Publication date:

2018-05

Permanent link:

https://doi.org/10.3929/ethz-b-000261752

Rights / license:

In Copyright - Non-Commercial Use Permitted

Originally published in:

Nature Climate Change 8, https://doi.org/10.1038/s41558-018-0131-z 


\title{
Historical deforestation locally
}

= increased the intensity of hot days in

\section{northern mid-latitudes}

\author{
Quentin Lejeune ${ }^{1 *}$ Edouard L. Davin ${ }^{1}$, Lukas Gudmundsson ${ }^{1}$, \\ Johannes WinckleR ${ }^{2}$ And Sonia I. Seneviratne ${ }^{1}$ \\ ${ }^{1}$ Institute for Atmospheric and Climate Science, ETH Zurich, Zurich, Switzerland \\ ${ }^{2}$ Max Planck Institute for Meteorology, Hamburg, Germany
}

October 31, 2017

\begin{abstract}
The effects of past land-cover changes on climate are disputed ${ }^{1,2,3}$. Prior modelling studies generally concluded that the biogeophysical effects of historical deforestation have led to an annual mean cooling in the northern mid-latitudes ${ }^{3,4}$, in line with the albedo-induced negative radiative forcing from land cover change since pre-industrial time reported in the last IPCC report ${ }^{5}$. However, further observational and modelling studies have highlighted strong seasonal and diurnal contrasts in the temperature response to deforestation ${ }^{6,7,8,9,10}$. Here we show that historical deforestation has led to a substantial local warming of hot days over the northern mid-latitudes, in contrast with most previous model results ${ }^{11,12}$. Based on observation-constrained state-of-theart climate model experiments, we estimate that moderate reductions in tree cover in these regions have contributed at least one third of the local present-day warming of the hottest day of the year since pre-industrial time, and were responsible for most of this warming before 1980. Our results emphasise that land-cover changes need to be considered when studying past and future changes in heat extremes, and highlight a potentially overlooked co-benefit of forest-based carbon mitigation through local biogeophysical mechanisms.

During the industrial period, large areas of primary vegetation like forests and natural grasslands were converted into croplands and pastures, in particular in northern mid-latitudes ${ }^{13}$. These land-
\end{abstract}

*Corresponding author: quentin.lejeune@env.ethz.ch 
cover changes (LCC) have had substantial impacts on climate by altering the carbon stocks, which contributed to the increase in the $\mathrm{CO}_{2}$ atmospheric concentration ${ }^{5}$ (biogeochemical effects), as well as by modifying land surface properties such as albedo, evapotranspiration efficiency and roughness, affecting the surface energy budget ${ }^{3,6,7,14}$ (biogeophysical effects). Even if the biogeophysical effects likely had limited consequences at the global scale, over some regions that have experienced extensive LCC they have impacted annual mean temperature by a similar magnitude as the concomitant increase in greenhouse gases ${ }^{3}$.

Previous modelling studies indicated significant biogeophysical impacts of historical LCC on hot days over mid-latitudes ${ }^{11,12,15}$. Most of them indicated a cooling effect, nevertheless there exists some model disagreement concerning the overall sign of these impacts. For example, three out of four climate models that took part in the model intercomparison project LUCID simulated a decrease in extremely warm daytime temperatures over the northern mid-latitudes during summer due to historical LCC ${ }^{11}$. However, the remaining model (IPSL) showed the opposite effect, in agreement with another similar study using the CSIRO-Mk3L model ${ }^{15}$. Consistent with the overall LUCID results, a detection and attribution study using optimal fingerprinting was conducted with the HadGEM2-ES model ${ }^{12}$, which suggested an LCC-induced cooling trend of extremely warm temperatures at the global scale, but especially in northern mid-latitudes over the last half of the $20^{t h}$ century. This lack of model agreement is not limited to hot days, as the sign of the impacts of historical LCC over these regions was found to be consistent between extremely warm daytime and mean summer temperatures within individual LUCID models ${ }^{11}$.

Recent observational studies enable to re-examine these modelling results under a new light ${ }^{8,9,10}$. In situ observations over North America comparing neighbouring measurement sites located over different land cover types indeed indicate that open lands are overall warmer than forests during daytime in summer ${ }^{8}$. Besides, global-scale studies based on satellite remote sensing have confirmed this finding ${ }^{9,10}$. In addition, satellite observations in the center of France showed that the higher surface temperatures over open lands compared to forests during daytime were exacerbated during heatwaves as opposed to normal summer conditions ${ }^{16}$. These findings based on spatial comparisons of present-day observations therefore suggest that historical deforestation may have amplified extremely warm temperatures during daytime.

In this study, we use recently released observational data to constrain the historical impact of deforestation on hot extremes in 11 models from the Coupled Model Intercomparison Project Phase 5 (CMIP $5^{17}$ ) that simulate the climate effect of LCC (see model list in Table 1). These fully-coupled models were found to be generally able to reproduce the spatial distribution and the trend patterns of hot temperature extremes from the gridded observational dataset HadEX $2^{18}$. On 
the basis of this ensemble, we estimate the local impacts of historical deforestation on mean daily maximum surface air temperature (TX) in the warm season, as well as on its yearly maximum value (TXx) from 1861 to 2000, compared to a pre-industrial control period. For this purpose, we use a recently developed methodology ${ }^{6,7}$ based on a comparison of historical temperature changes over neighbouring areas that have experienced different deforestation rates (see Methods). One advantage of the reconstruction method is that it can be directly applied to historical simulations considering all climate forcings, without the need for additional factorial experiments isolating the effect of the land use forcing. This method compares nevertheless well with results from the more classical factorial method (see Supplementary Fig. 1).

We find that only 5 out of the 11 CMIP 5 models show the same sign as in situ observations with respect to summer daytime temperature sensitivity to deforestation: CanESM2, IPSL-CM5A-LR, IPSL-CM5A-MR, MPI-ESM-LR and MPI-ESM-MR (Table 1 and Supplementary Fig. 2). In the rest of this study, we therefore focus on the results of these 5 selected models and their multimodel mean (M-M M), on the ground that they capture more realistically the response of summer daytime temperature to deforestation, which is most relevant for our investigation of changes in hot extremes.

The constrained M-M M shows that historical deforestation has led to local increases in TXx over extensive parts of North America, Eurasia and South Asia, but also southern South America, eastern Australia and southeastern Africa during present-day (1981-2000) compared to pre-industrial conditions (Fig. 1). At least three of the five selected models agree that this warming is significant for large areas of North America and Eurasia. In contrast, a few regions have experienced a cooling in response to deforestation (mostly southeastern Brazil), but only a minority of models indicate that this result is significant. The strongest deforestation-induced warming of TXx has occurred over North America and Eurasia, where it reaches $0.3^{\circ} \mathrm{C}$ on average (over areas that have been at least moderately deforested, encircled in green in Fig. 1), and up to $1^{\circ} \mathrm{C}$ locally over the Great Plains. The M-M M warming is more moderate over South Asia $\left(0.1^{\circ} \mathrm{C}\right)$, with only the CanESM2 model showing significant changes. The sign of the impacts of historical deforestation is consistent between TXx and JJA TX within each model. Besides, despite a substantial spread between estimates from individual models, there is a tendency among most of the selected models to simulate slightly (non-significantly) higher impacts of deforestation on extremely warm than on mean summer daytime temperature (Fig. 1).

Based on the M-M M, we infer a local sensitvity of TXx and mean June-July-August (JJA) TX to deforestation of respectively $0.12 \pm 0.001^{\circ} \mathrm{C}$ and $0.08 \pm 0.001^{\circ} \mathrm{C}$ for a $10 \%$ decrease in tree cover over North America and Eurasia (Fig. 2 and Table 2). These figures have remained fairly 
constant along the industrial period (Supplementary Table 2). In comparison, a recent satellitebased study indicated an increase in JJA TX by $0.3-0.6^{\circ} \mathrm{C}$ per $10 \%$ of deforestation based on observations for the 2003-2012 period over temperate, boreal and arid areas ${ }^{10}$. These observational estimates hence constitute further indication that the selected models correctly simulate the sign of the response of summer TX to deforestation over mid-latitudes. Besides, they suggest that the M-M M sensitivities may be underestimates, although methodological differences in the employed reconstruction method as well as in the regions over which results were averaged could impart a precise quantitative comparison between the mentioned observational results and ours.

Extensive deforestation took place early in the industrial period over the northern mid-latitudes. By 1920, the resulting M-M M increases in TXx through biogeophysical effects had already reached $0.3^{\circ} \mathrm{C}$ ( $\sim 75 \%$ of their present-day values) over the most deforested areas of North America and Eurasia (Fig. 3). On average before 1920, local deforestation was responsible for most of the TXx warming over these regions, while other forcings and internal variability had overall led to no changes over North America and to a cooling over Eurasia. Our reconstructions show that the deforestation-induced increase in TXx then levelled off over the rest of the $20^{\text {th }}$ century due to the slowing down of deforestation in northern mid-latitudes. Over this period, the influence of other forcings gradually became more important, leading to a total warming by $1.3^{\circ} \mathrm{C}$ over North America and $1^{\circ} \mathrm{C}$ over Eurasia by present-day $\left(0.9-1.8^{\circ} \mathrm{C}\right.$, respectively $0.5-1.5^{\circ} \mathrm{C}$ depending on the models). The relative contribution of the biogeophysical effects of deforestation still remained as high as $56 \%$ (20-115\%) over North America and 32\% (between 22\% and 7 times higher, depending on the models) over Eurasia on average between 1920 and 1980. It decreased to $30 \%$ on average over the more recent 1981-2000 period, although this estimate is very much model-dependent (Fig. 1). Considering additionally that forest removal accounted globally for $30 \%$ of the cumulative carbon emissions since $1850^{19,20}$, deforestation was responsible for at least another $20 \%$ of the increase in TXx between 1861 and 2000 over the considered regions, according to the M-M M (see Methods for more details).

The local warming signal of deforestation presented in this study is based on modelling evidence constrained by present-day observations. An open question is the possibility of its direct identification in observational records. However, this still requires overcoming the following issues: the absence of long-term temperature measurements over forests (because weather stations are required to be located over short vegetation types), the high internal variability that prevails at regional scale ${ }^{21}$, uncertainties in both climate records and land-use reconstructions for the early industrial period $^{13,22}$, as well as the intertwining of the historical deforestation signal with that of other related processes such as irrigation or land management. These were indeed shown to have 
strongly influenced historical trends in regional temperatures ${ }^{23,24,25}$, but are often not represented in current climate models. Therefore, the development of appropriate tools to identify the local signature of deforestation in observations constitutes an important challenge, in particular for the detection and attribution community.

Our analysis also confirms the difficulty to capture the biogeophysical impacts of LCC on temperature using global metrics such as the Radiative Forcing Framework ${ }^{14,26}$. This framework which is classically used to compare climate forcings - indeed only considers albedo changes following deforestation, which have a cooling impact ${ }^{3,7}$. It thus fails to capture the non-radiative effects (such as changes in the partitioning of turbulent fluxes), which play a dominant role in the summer response to deforestation ${ }^{7}$. The historical deforestation-induced increase in the intensity of hot days described in this study does not align either with the associated albedo decrease reported over the same period ${ }^{5}$, and therefore reaffirms that the Radiative Forcing framework is of limited usefulness when investigating the climate consequences of land-use practices.

In conclusion, our results shed new light on the importance of LCC for the historical evolution of hot extremes at regional scales. Contrary to many previous studies which suggested that the biogeophysical effects of historical deforestation had mitigated daytime hot extremes over midlatitudinal regions ${ }^{11,12}$, this observation-constrained analysis of CMIP5 models shows that they have actually led to significant local increases in TXx over many areas in the world. They were responsible for at least half of the warming of TXx over most-deforested mid-latitudinal regions by as far as 1980. Besides our best estimate suggests that the present-day contribution of deforestation to the TXx increase over this region still equals at least $50 \%$ once the warming entailed by the LCCinduced carbon emissions is also considered. This also has implications for future land-use policies. In fact, although a small biogeophysical increase of annual mean temperature in temperate regions has previously been mentioned as a possible consequence of afforestation or reforestation policies that would be primarily designed for carbon dioxide removal ${ }^{27,28,29}$, our study suggests that they could locally help reduce the intensity of heat extremes. It is thus of critical importance to better account for biogeophysical effects of LCC in historical simulations and climate projections, as well as in upcoming IPCC assessments. 
154

\section{Methods}

\section{CMIP5 simulations}

We analyse historical ("all-forcings") as well as pre-industrial control (piControl) simulations from 11 CMIP5 models for which daily maximum surface air temperature values at daily resolution as well as land cover information are available. The ensemble size and the references for each model are indicated in Supplementary Table 1. We first compute mean TXx and JJA TX values over each land grid cell and for seven 20-year periods: 1861-1880, 1881-1900, 1901-1920, 1921-1940, 1941-1960, 1961-1980 and 1981-2000. We then compare them to their average values over the first 200 years of the piControl simulations. After calculation of the reconstructed effects of deforestation, the results from each model were regridded on a common $2.5^{\circ} \times 2.5^{\circ}$ grid using a bilinear interpolation method. Because IPSL-CM5A-LR and IPSL-CM5A-MR are two versions of the same model, we have assigned to them only half of the weight given to CanESM2 in the calculation of the M-M M. The same procedure was applied to MPI-ESM-LR and MPI-ESM-MR.

\section{Local impacts of deforestation on temperature}

We reconstruct the local impacts of historical deforestation on mean JJA TX and on TXx by fitting linear regressions between the simulated temporal changes in these variables and those in tree fraction within spatially moving windows encompassing $5 \times 5$ model grid cells (also called "big boxes"). This method assumes that LCC constitute a spatially heterogeneous forcing which mostly impacts temperature in each grid cell individually, in contrast to other climate forcings like greenhouse gases (GHG) which affect temperature similarly in all grid cells from a same big box. Similar methodologies based on this same assumption were already employed to analyse CMIP5 $\operatorname{models}^{6,7}$.

In practical terms, to derive the changes in TXx due to local deforestation over a given land grid cell $i\left(\delta T X x_{\mathrm{def}}(i)\right)$, we consider a big box of a size of $5 \mathrm{X} 5$ grid cells centered over $i$. Within this big box, for every 20-year period the total changes in TXx $(\delta T X x)$ for each land grid cell are modelled by linear regression using four spatial predictors: the deforestation rate experienced by the grid cells between the pre-industrial period and the period of interest (defrate), their latitude (lat), longitude (lon) and elevation (elev), such that:

$$
\delta T X x=\beta_{0}+\beta_{1} \times \text { defrate }+\beta_{2} \times \text { lat }+\beta_{3} \times \text { lon }+\beta_{4} \times \text { elev } .
$$

defrate, lat, lon and elev are here vectors containing up to 25 values, while the $\beta$ coefficients 
are specific to each 20-year period and each particular big box. $\delta T X x_{d e f}(i)$ is then obtained by scaling the results of this local regression with the deforestation rate experienced over $i$ (compared to pre-industrial):

$$
\delta T X x_{\operatorname{def}}(i)=\beta_{1} \times \operatorname{defrate}(i)
$$

We apply the same method to simulate changes in mean JJA TX. Previous studies based on similar methodologies employed another approach to separate the grid cells within each big box in two bins. They indeed used an ad hoc threshold corresponding to a critical change in either crop ${ }^{6}$ or tree fraction ${ }^{7}$. The suitability of the threshold-based method to investigate the local impacts of historical LCC on seasonal mean albedo, surface heat fluxes and surface air temperature was previously demonstrated ${ }^{7}$, showing that it gives similar results to the more commonly used factorial experiment method (i.e. the difference between a model experiment in which the land-cover forcing is applied and a control one). Here we apply the regression-based reconstruction method over each land grid cell for which the corresponding big box contains at least 15 land grid cells, which is an advantage compared to the threshold-based approach that could only be applied to grid cells where the intensity of historical LCC exceeded the specified ad hoc threshold. We chose to use three spatial predictors (latitude, longitude, and elevation) in addition to the deforestation rate experienced by the grid cells, because we found that this limits the reconstruction of false deforestation signals or artefacts, which are in reality due to natural climatic gradients within the big boxes and not related to variations in the LCC forcing. We find that the regression-based reconstruction method tends to estimate smaller deforestation-induced temperature changes compared to the factorial experiment approach, for some of the models for which both methods are applicable (Supplementary Fig. 1). This tendency had already been noted for the threshold-based method ${ }^{7}$. Besides, our results indicate that the reconstruction method is less subject to internal variability than the factorial experiment one (Supplementary Fig. 1).

\section{Estimating uncertainty of the reconstruction method}

An uncertainty range for the reconstructed signal is computed by applying the regression to each ensemble simulation of a given model. In addition, for each ensemble simulation and each big box a jackknife resampling is also conducted: Alternatively, and as many times as there are land grid cells with non-missing values in the big box, the values from one grid cell are systematically left out before the regression is computed again based on this new sample ${ }^{30}$. Depending on the number of land grid cells in the big box, we thus obtain betwen 16 and 26 estimates of $\delta T X x_{d e f}$ and $\delta T X_{d e f}^{J J A}$ 
for each land grid cell of each ensemble simulation. We then retain the median of these estimates, which increases the robustness of our results by eliminating strong dependences on single model grid cells. The confidence intervals shown in Fig. 1 were also derived from this jackknife resampling process.

\section{Biogeochemical effects of deforestation}

$30 \%$ of the present-day increase in TXx over the parts of North America and Eurasia that experienced at least moderate deforestation $(>15 \%)$ along the industrial period is due to its biogeophysical effects (Fig. 3). The remaining 70\% are resulting from other forcings included in CMIP5 (aerosols, volcanic emissions, and greenhouse gases ${ }^{17}$ ). Because aerosols and volcanic emissions overall have a cooling effect ${ }^{5}$, the greenhouse gas forcing is responsible for at least $70 \%$ of this increase. Note that this is a very conservative estimate, however the exact contributions from each forcing are missing for the 1861-2000 period, and estimating them precisely is out of the scope of this study. Furthermore, global assessments of carbon emissions based on bookkeeping methods concluded that over the 1861-2000 period land-use changes were responsible for 33\% of the cumulative carbon emissions ${ }^{19,20}$ (i.e., the net balance between emissions from all types of land disturbances and forest regrowth). Changes in forest area overall acounted for $90 \%$ of this flux ${ }^{19,31}$, which means that net deforestation was responsible for $30 \%$ of the cumulative carbon emissions between 1861 and 2000 . The biogeochemical effects of deforestation thus led to $30 \%$ of the changes in TXx due to the greenhouse gas forcing. Greenhouse gas emissions from 1861 to 2000 are responsible for at least $70 \%$ of the total present-day change in TXx over the regions analysed in Fig. 3 (see above), therefore we estimate that at least $21 \%$ of this change is due to the biogeochemical effects of deforestation. This means that the combined biogeophysical and biogeochemical effects have made up for more than half of this increase.

\section{References}

[1] R. Mahmood, R. A. Pielke Sr., K. G. Hubbard, D. Niyogi, P. A. Dirmeyer, C. McAlpine, A. M. Carleton, R. Hale, S. Gameda, A. Beltrán-Przekurat, B. Baker, R. McNider, D. R. Legates, M. Shepherd, J. Du, P. D. Blanken, O. W. Frauenfeld, U. S. Nair, and S. Fall, "Land cover changes and their biogeophysical effects on climate," International Journal of Climatology, vol. 34, pp. 929-953, 2014. 
[2] A. J. Pitman, N. de Noblet-Ducoudré, F. T. Cruz, E. L. Davin, G. B. Bonan, V. Brovkin, M. Claussen, C. Delire, L. Ganzeveld, V. Gayler, B. van der Hurk, P. Lawrence, M. van der Molen, C. Müller, C. Reick, S. Seneviratne, B. Strengers, and A. Voldoire, "Uncertainties in climate responses to past land cover change: First results from the LUCID intercomparison study," Geophysical Research Letters, vol. 36, p. L14814, 2009.

[3] N. de Noblet-Ducoudré, J.-P. Boisier, A. J. Pitman, G. B. Bonan, V. Brovkin, F. Cruz, C. Delire, V. Gayler, B. van der Hurk, P. Lawrence, M. van der Molen, C. Müller, C. Reick, B. Strengers, and A. Voldoire, "Determining robust impacts of land-use-induced land cover changes on surface climate over North America and Eurasia: Results from the first set of LUCID experiments," J. Climate, vol. 25, pp. 3261-3281, 2012.

[4] V. Brovkin, M. Claussen, E. Driesschaert, T. Fichefet, D. Kicklighter, M. F. Loutre, H. D. Matthews, N. Ramankutty, M. Schaeffer, and A. Sokolov, "Biogeophysical effects of historical land cover changes simulated by six earth system models of intermediate complexity," Climate Dynamics, vol. 26, no. 6, pp. 587-600, 2006.

[5] IPCC, Climate Change 2013: Working Group I Contribution to the IPCC Fifth Assessment Report: The Physical Science Basis. Cambridge, United Kingdom and New York, NY, USA: Cambridge University Press, 2013.

[6] S. Kumar, P. A. Dirmeyer, V. Merwade, T. DelSole, J. M. Adams, and D. Niyogi, "Land use/cover change impacts in CMIP5 climate simulations: A new methodology and 21st century challenges," J. Geophys. Res.: Atmos., vol. 118, pp. 6337-6353, 2013.

[7] Q. Lejeune, S. I. Seneviratne, and E. L. Davin, "Historical land-cover change impacts on climate: Comparative assessment of LUCID and CMIP5 multimodel experiments," Journal of Climate, vol. 30, no. 4, pp. 1439-1459, 2017.

[8] X. Lee, M. L. Goulden, D. Y. Hollinger, A. Barr, T. A. Black, G. Bohrer, R. Bracho, B. Drake, A. Goldstein, L. Gu, G. Katul, T. Kolb, B. Law, H. Margolis, T. Meyers, R. Monson, W. Munger, R. Oren, K. T. U, A. Richardson, H. P. Schmid, R. Staebler, S. Wofsy, and L. Zhao, "Observed increase in local cooling effect of deforestation at higher latitudes," Nature, vol. 479, pp. 384-387, 2011.

[9] Y. Li, M. Zhao, S. Motesharrei, Q. Mu, E. Kalnay, and S. Li, "Local cooling and warming effects of forests based on satellite observations," Nature Communications, vol. 6, pp. 6603 EP -, 032015. 
[10] R. Alkama and A. Cescatti, "Biophysical climate impacts of recent changes in global forest cover," Science, vol. 351, pp. 600-604, 2016.

[11] A. J. Pitman, N. de Noblet-Ducoudré, F. B. Avila, L. V. Alexander, J.-P. Boisier, V. Brovkin, C. Delire, F. Cruz, M. G. Donat, V. Gayler, B. van der Hurk, C. Reick, and A. Voldoire, "Effects of land cover change on temperature and rainfall extremes in multi-model ensemble simulations," Earth System Dynamics, vol. 3, pp. 213-231, 2012.

[12] N. Christidis, P. A. Stott, G. C. Hegerl, and R. A. Betts, "The role of land use change in the recent warming of daily extreme temperatures," Geophys. Res. Lett., vol. 40, pp. 589-594, 2013.

[13] K. Klein Goldewijk, A. Beusen, G. van Drecht, and M. de Vos, "The HYDE 3.1 spatially explicit database of human-induced land use change over the past 12,000 years," Glob. Ecol. Biogeogr., vol. 20, pp. 73-86, 2011.

[14] E. L. Davin, N. de Noblet-Ducoudré, and P. Friedlingstein, "Impact of land cover change on surface climate: Relevance of the radiative forcing concept," Geophysical Research Letters, vol. 34 , no. $13,2007$.

[15] F. B. Avila, A. J. Pitman, M. G. Donat, L. V. Alexander, and G. Abramowitz, "Climate model simulated changes in temperature extremes due to land cover change," J. Geophys. Res.: Atmos., vol. 117, no. D04108, 2012.

[16] B. F. Zaitchik, A. K. Macalady, L. R. Bonneau, and R. B. Smith, "Europe's 2003 heat wave: A satellite view of impacts and land-atmosphere feedbacks," Int. J. of Climatol., vol. 26, pp. 743769,2006

[17] K. E. Taylor, R. J. Stouffer, and G. A. Meehl, "An overview of CMIP5 and the experiment design," Bull. Amer. Meteor. Soc., vol. 93, pp. 485-498, 2012.

[18] J. Sillmann, V. Kharin, X. Zhang, F. Zwiers, and D. Bronaugh, "Climate extremes indices in the CMIP5 multimodel ensemble: Part 1. Model evaluation in the present climate," J. Geophys. Res.: Atmos., vol. 118, pp. 1716-1733, 2013.

[19] R. A. Houghton, "The annual net flux of carbon to the atmosphere from changes in land use 1850-1990*," Tellus B, vol. 51, no. 2, pp. 298-313, 1999.

[20] C. Le Quéré, R. M. Andrew, J. G. Canadell, S. Sitch, J. I. Korsbakken, G. P. Peters, A. C. Manning, T. A. Boden, P. P. Tans, R. A. Houghton, R. F. Keeling, S. Alin, O. D. Andrews, 
P. Anthoni, L. Barbero, L. Bopp, F. Chevallier, L. P. Chini, P. Ciais, K. Currie, C. Delire, S. C. Doney, P. Friedlingstein, T. Gkritzalis, I. Harris, J. Hauck, V. Haverd, M. Hoppema, K. Klein Goldewijk, A. K. Jain, E. Kato, A. Körtzinger, P. Landschützer, N. Lefèvre, A. Lenton, S. Lienert, D. Lombardozzi, J. R. Melton, N. Metzl, F. Millero, P. M. S. Monteiro, D. R. Munro, J. E. M. S. Nabel, S.-I. Nakaoka, K. O’Brien, A. Olsen, A. M. Omar, T. Ono, D. Pierrot, B. Poulter, C. Rödenbeck, J. Salisbury, U. Schuster, J. Schwinger, R. Séférian, I. Skjelvan, B. D. Stocker, A. J. Sutton, T. Takahashi, H. Tian, B. Tilbrook, I. T. van der Laan-Luijkx, G. R. van der Werf, N. Viovy, A. P. Walker, A. J. Wiltshire, and S. Zaehle, "Global carbon budget 2016," Earth System Science Data, vol. 8, no. 2, pp. 605-649, 2016.

[21] P. A. Stott, N. P. Gillett, G. C. Hegerl, D. J. Karoly, D. A. Stone, X. Zhang, and F. Zwiers, "Detection and attribution of climate change: a regional perspective," Wiley Interdisciplinary Reviews: Climate Change, vol. 1, no. 2, pp. 192-211, 2010.

[22] M. Donat, L. Alexander, H. Yang, I. Durre, R. Vose, R. Dunn, K. Willett, E. Aguilar, M. Brunet, J. Caesar, et al., "Updated analyses of temperature and precipitation extreme indices since the beginning of the twentieth century: the HadEX2 dataset," Journal of Geophysical Research: Atmospheres, vol. 118, no. 5, pp. 2098-2118, 2013.

[23] B. I. Cook, R. L. Miller, and R. Seager, "Amplification of the North American "Dust Bowl" drought through human-induced land degradation," Proceedings of the National Academy of Sciences, vol. 106, no. 13, pp. 4997-5001, 2009.

[24] N. D. Mueller, E. E. Butler, K. A. McKinnon, A. Rhines, M. Tingley, N. M. Holbrook, and P. Huybers, "Cooling of US Midwest summer temperature extremes from cropland intensification," Nature Clim. Change, vol. 6, pp. 317-322, 032016.

[25] W. Thiery, E. L. Davin, D. M. Lawrence, A. L. Hirsch, M. Hauser, and S. I. Seneviratne, "Present-day irrigation mitigates heat extremes," Journal of Geophysical Research: Atmospheres, vol. 122, no. 3, pp. 1403-1422, 2017.

[26] R. M. Bright, E. Davin, T. O/'Halloran, J. Pongratz, K. Zhao, and A. Cescatti, "Local temperature response to land cover and management change driven by non-radiative processes," Nature Clim. Change, vol. 7, pp. 296-302, 042017.

[27] R. A. Betts, "Offset of the potential carbon sink from boreal forestation by decreases in surface albedo," Nature, vol. 408, pp. 187-190, 112000. 
[28] V. K. Arora and A. Montenegro, "Small temperature benefits provided by realistic afforestation efforts," Nature Geosci, vol. 4, pp. 514-518, 082011.

[29] J. Schwaab, M. Bavay, E. Davin, F. Hagedorn, F. Hüsler, M. Lehning, M. Schneebeli, E. Thürig, and P. Bebi, "Carbon storage versus albedo change: radiative forcing of forest expansion in temperate mountainous regions of Switzerland," Biogeosciences, vol. 12, no. 2, pp. 467-487, 2015.

[30] B. Efron, The Jackknife, the Bootstrap and Other Resampling Plans. Society for Industrial and Applied Mathematics, 1982.

[31] R. A. Houghton, "Revised estimates of the annual net flux of carbon to the atmosphere from changes in land use and land management 1850-2000," Tellus B, vol. 55, no. 2, pp. 378-390, 2003.

\section{Acknowledgements}

We acknowledge partial support from the European Union through the projects FP7 EMBRACE (Grant Agreement 282672), H2020 CRESCENDO (Grant Agreement 641816), and ERC DROUGHTHEAT (Contract 617518). We also acknowledge the World Climate Research Programme's Working Group on Coupled Modeling, which is responsible for CMIP, and we thank the climate modeling groups who took part in this project for producing and making available their model output. For CMIP, the U.S. Department of Energy's Program for Climate Model Diagnosis and Intercomparison provides coordinating support and led development of software infrastructure in partnership with the Global Organization for Earth System Science Portals. We also thank Chris Jones, Vivek Avora, Ingo Bethke, and Dave Lawrence for providing additional data from CMIP5 simulations, and we are very grateful to Urs Beyerle for his management of the CMIP5 database at ETH. Finally, we thank Xuhui Lee and colleagues for making the observational data available.

\section{Author contributions}

Q.L. performed the analysis of the models, all authors helped develop the methodology and contributed to the writing. 


\section{Competing Financial Interests}

The authors declare no competing financial interests.

\section{Figure Legends}

Figure 1: Reconstructed local effects of deforestation on TXx and JJA TX for presentday (1981-2000) compared to pre-industrial conditions. The map shows multi-model mean (M-M M) estimates of the local changes in the annual maximum value of surface air temperature (TXx) due to deforestation, with the stippling indicating areas where at least three models show changes of the same sign that are significant at the $5 \%$ level. The insets show the average changes in mean June-July-August surface air temperature (JJA TX, yellow) and TXx (red) due to deforestation (filled bars) and to other forcings (hatched bars) for each of the selected models and the multi-model mean (M-M M), with the black vertical lines indicating $90 \%$ of the spread in the reconstructions for the individual models, and the model spread in the case of the M-M M. Results were averaged over the areas of North America, Eurasia and South Asia that have experienced at least $15 \%$ of deforestation according to the M-M M (encircled in green).

Figure 2: Sensitivity of mean daily maximum surface air temperature during JuneJuly-August (JJA TX, yellow) and its yearly maximum value (TXx, red) to deforestation over North America and Eurasia. The reconstructed local effects of deforestation are plotted against the deforestation rate, for each of the selected models and the multi-model mean (M-M M). Each dot represents the reconstructed change in one of the temperature indices over one grid cell of these regions (shown in black in Fig. 1), averaged over a 20-year period of the full analysis period (i.e. 1861-1880, 1881-1900, etc.). The yellow and red lines show linear regressions without intercept within the data clouds of the corresponding colours (the red dots were plotted over the yellow ones). The values of the sensitivities to $10 \%$ of deforestation based on these regressions are shown in Table 2.

Figure 3: Importance of the local effects of deforestation in the historical evolution of TXx over North America and Eurasia. The red and blue lines indicate the multi-model mean estimates of the changes in the hottest surface air temperature of the year (TXx) due to deforestation and to all forcings combined, respectively, on average over the regions highlighted in green in Fig. 1. The envelopes in light blue and light red show the spread between the selected models. The contribution of the deforestation-induced local changes in TXx to its total changes are indicated by the green bars in the lower panels. 
Table 1: Change in June-July-August TXx due to deforestation over North America, in historical CMIP5 model simulations and in present-day observations ${ }^{8}$.

\begin{tabular}{ll}
\hline Model name & JJA $\delta T X_{\text {def }}$ over North \\
& America $\left({ }^{\circ} \mathrm{C}\right)$ \\
\hline CanESM2 & $\mathbf{0 . 7 7}[0.59,0.88]$ \\
CCSM4 & $-0.09[-0.14,-0.04]$ \\
GFDL-CM3 & $-0.06[-0.26,0.13]$ \\
GFDL-ESM2-G & $0.00[-0.03,0.04]$ \\
GFDL-ESM2-M & $-0.04[-0.07,-0.00]$ \\
HadGEM2-ES & $-0.44[-0.55,-0.34]$ \\
IPSL-CM5A-LR & $\mathbf{0 . 2 7}[0.15,0.40]$ \\
IPSL-CM5A-MR & $\mathbf{0 . 1 8}[0.070 .30]$ \\
MPI-ESM-LR & $\mathbf{0 . 1 2}[-0.01,0.27]$ \\
MPI-ESM-MR & $\mathbf{0 . 2 2}[0.09,0.36]$ \\
NorESM1-M & $-0.17[-0.29,-0.08]$ \\
\hline Observations & $\mathbf{1 . 1 6}[0.26,1.85]$ \\
\hline
\end{tabular}

Mean model estimates show changes by present-day (1981-2000) compared to pre-industrial, and are calculated over grid cells where the deforestation rate between these two periods has exceeded $15 \%$. The numbers in brackets indicate $90 \%$ of the spread in the reconstructions for the models, and the interquartile range between individual paired measurement sites for the observations. Models for which the sign of the impact of deforestation is consistent with observations are highlighted in bold.

${ }_{391}$ Tables 
Table 2: Sensitivity of June-July-August (JJA) TX and TXx to deforestation over North America and Eurasia.

\begin{tabular}{llc}
\hline Model & \multicolumn{2}{c}{$\delta T X_{\text {def }}$ per $10 \%$ deforestation $\left({ }^{\circ} \mathrm{C}\right)$} \\
\hline CanESM2 & JJA & TXx \\
IPSL-CM5A-LR & $0.25[0.002]$ & $0.35[0.002]$ \\
IPSL-CM5A-MR & $0.11[0.001]$ & $0.14[0.001]$ \\
MPI-ESM-LR & $0.10[0.001]$ & $0.10[0.001]$ \\
MPI-ESM-MR & $0.02[0.001]$ & $0.07[0.002]$ \\
M-M M & $0.03[0.001]$ & $0.06[0.002]$ \\
\hline
\end{tabular}

Values correspond to the coefficients of the linear regressions presented in Fig. 2. Standard errors are indicated in brackets. 


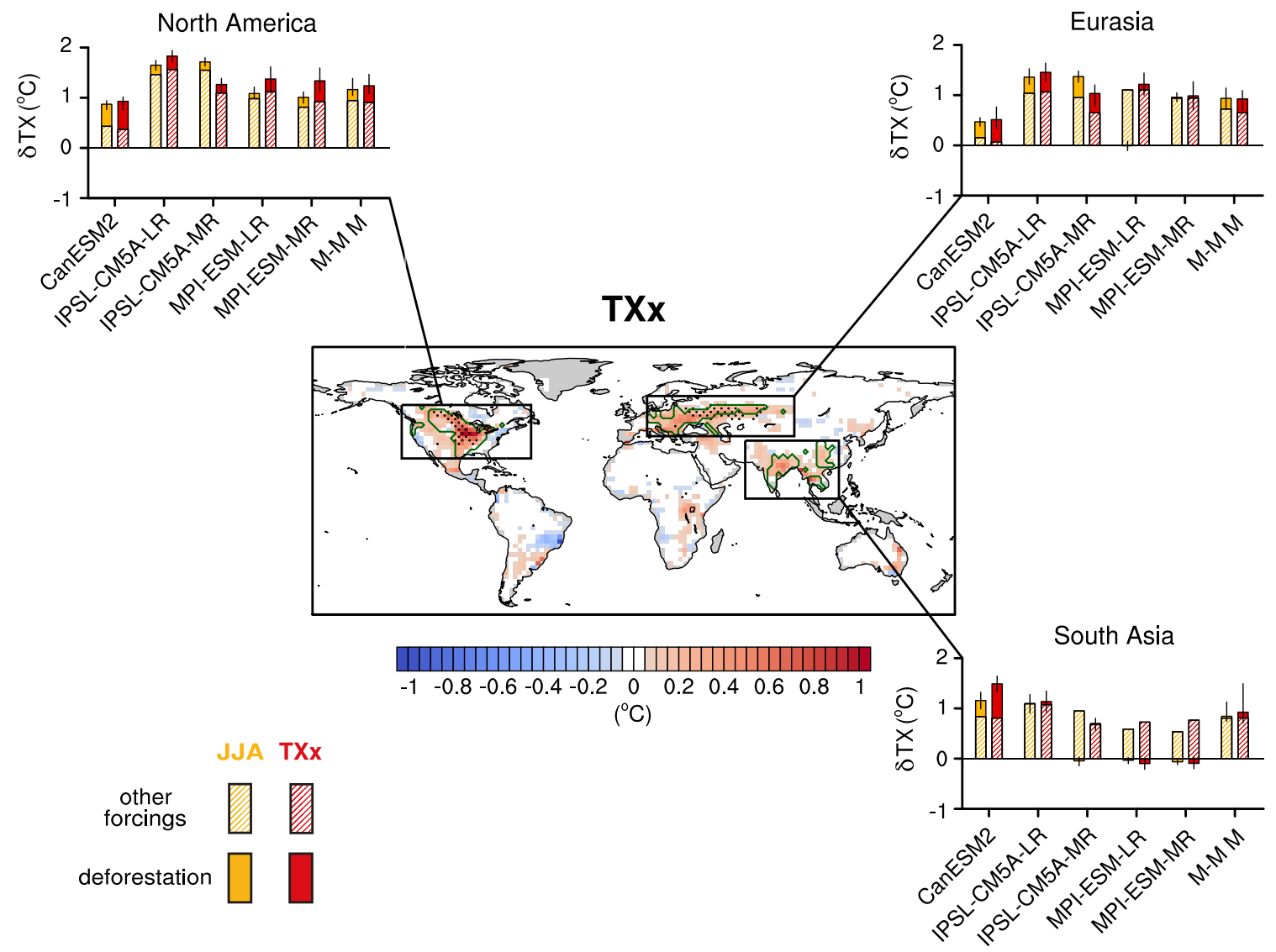

Figure 1: Reconstructed local effects of deforestation on TXx and JJA TX for presentday (1981-2000) compared to pre-industrial conditions. The map shows multi-model mean (M-M M) estimates of the local changes in the annual maximum value of surface air temperature (TXx) due to deforestation, with the stippling indicating areas where at least three models show changes of the same sign that are significant at the $5 \%$ level. The insets show the average changes in mean June-July-August surface air temperature (JJA TX, yellow) and TXx (red) due to deforestation (filled bars) and to other forcings (hatched bars) for each of the selected models and the multi-model mean (M-M M), with the black vertical lines indicating $90 \%$ of the spread in the reconstructions for the individual models, and the model spread in the case of the M-M M. Results were averaged over the areas of North America, Eurasia and South Asia that have experienced at least $15 \%$ of deforestation according to the M-M M (encircled in green). The same areas are considered in Fig.3, while all the land grid cells within the regions highlighted in black were included in Fig.2. 


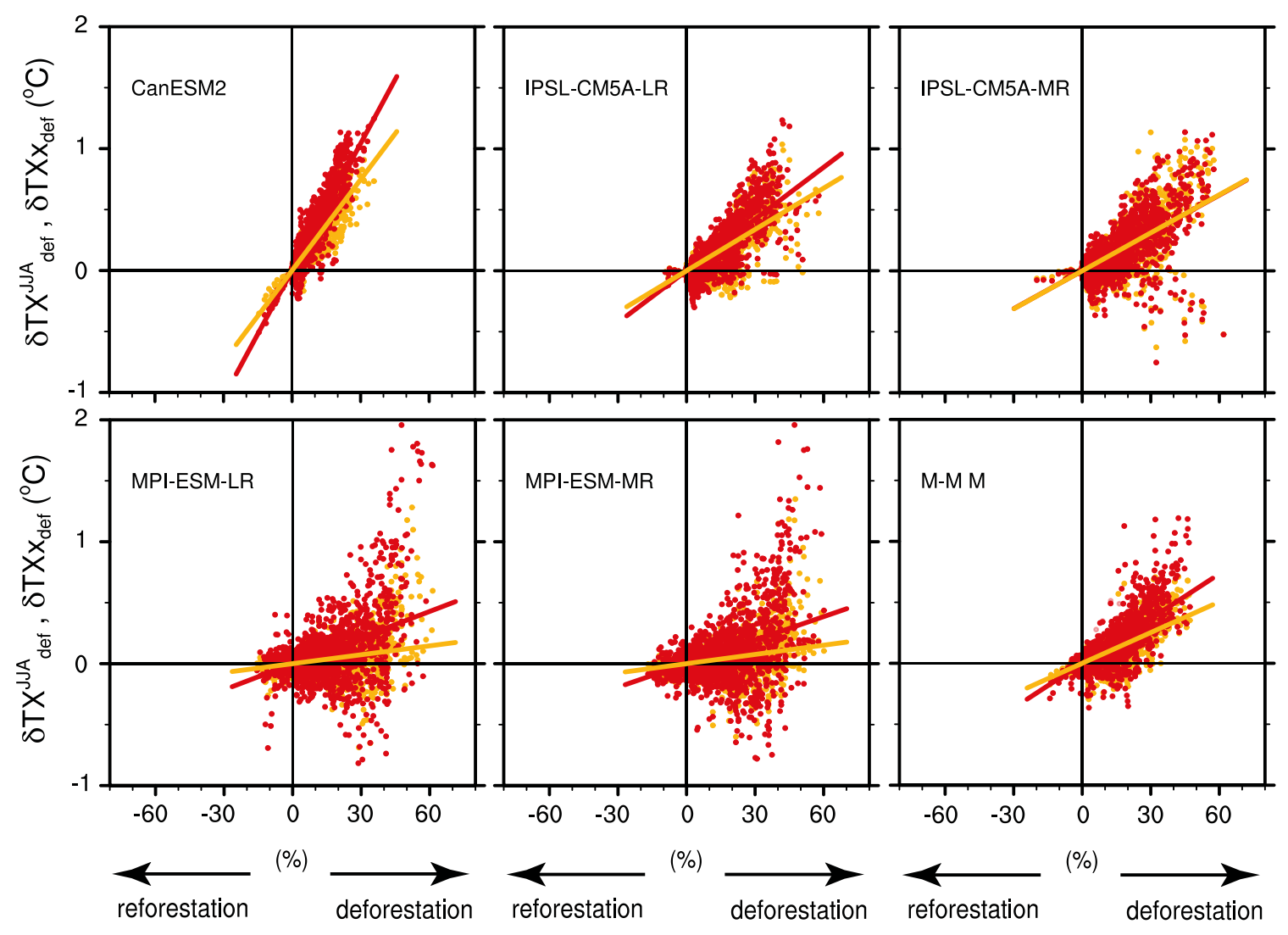

Figure 2: Sensitivity of JJA TX and TXx to deforestation over North America and

Eurasia. The reconstructed local effects of deforestation on mean daily maximum surface air temperature during June-July-August (JJA TX, yellow) and its yearly maximum value (TXx, red) are plotted against the deforestation rate, for each of the selected models and the multi-model mean (M-M M). Each dot represents the reconstructed change in one of the temperature indices over one grid cell of these regions (shown in black in Fig. 1), averaged over a 20-year period of the full analysis period (i.e. 1861-1880, 1881-1900, etc.). The yellow and red lines show linear regressions without intercept within the data clouds of the corresponding colours (the red dots were plotted over the yellow ones). The values of the sensitivities to $10 \%$ of deforestation based on these regressions are shown in Table 2. 

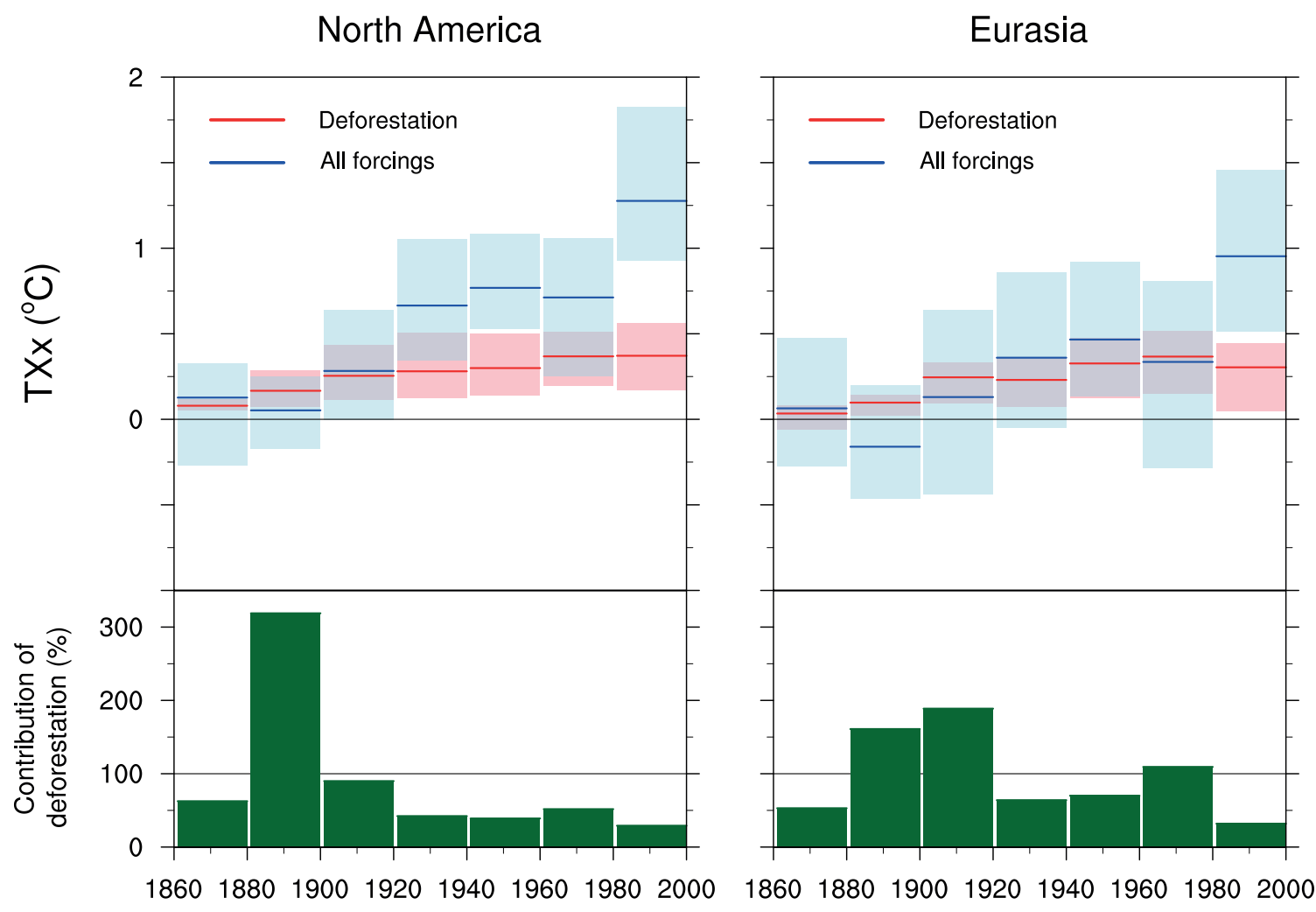

Figure 3: Importance of the local effects of deforestation in the historical evolution of TXx over North America and Eurasia. The red and blue lines indicate the multi-model mean estimates of the changes in the hottest temperature of the year (TXx) due to deforestation and to all forcings combined, respectively, on average over the regions highlighted in green in Fig. 1. The envelopes in light blue and light red show the spread between the selected models. The contribution of the deforestation-induced local changes in TXx to its total changes are indicated by the green bars in the lower panels. 